PROCEDIA

Studi Kasus dan Intervensi Psikologi

ISSN:2302-1462; e-ISSN: 2722-7669

Volume 8(4) 170-177, Desember 2020

DOI: $10.22219 /$ procedia.v8i4.14788

\title{
Latihan keterampilan sosial untuk meningkatkan penerimaan sosial pada anak dengan social (pragmatic) communication disorder
}

Baiq Sopia Iswari Azizah, Universitas Muhammadiyah Malang, Malang, Indonesia Iswinarti, Universitas Muhammadiyah Malang, Malang, Indonesia

Korespondonesi:

Baiq Sopia Iswari Azizah, email: sopiabaiq@gmail.com

\begin{abstract}
Riwayat artikel
Naskah diterima:

09/09/2020

Revisi diterima:

$21 / 11 / 2020$

Naskah disetujui:

$07 / 12 / 2020$

Abstrak

Social (Pragmatic) Communication Disorder (SCD) merupakan gangguan komunikasi yang terjadi pada anak-anak. Subjek berusia 8 tahun memiliki permasalahan kurangnya penerimaan sosial. Berdasarkan hasil asesmen dengan menggunakan wawancara, observasi, grafis, dan WISC, subjek didiagnosa memiliki gangguan social (pragmatic) communication disorder dengan permasalahan kurangnya penerimaan sosial. Kurangnya penerimaan sosial yang terjadi pada subjek diakibatkan subjek kurang mampu dalam interaksi sosial. Intervensi yang digunakan pada kasus ini adalah dengan latihan keterampilan sosial. Tujuan dari intervensi ini yaitu untuk meningkatkan penerimaan sosial pada subjek yang memiliki social (pragmatic) communication disorder. Hasil intervensi menunjukkan perubahan yang lebih baik dari diri subjek. Subjek lebih diterima oleh teman-teman sebayanya sehingga penerimaan sosial subjek meningkat. Kata kunci: Social (Pragmatic) Communication Disorder, latihan keterampilan sosial, penerimaan sosial.
\end{abstract}

\section{Latar Belakang}

Social (Pragmatic) Communication Disorder (SCD) merupakan gangguan komunikasi yang terjadi pada anak-anak. SCD merupakan gangguan yang terdapat pada neurodevelopmental disorder dimana individu kesulitan dalam menggunakan bahasa untuk kontek sosial, berdampak pada kemampuan individu untuk beradaptasi dengan gaya komunikasinya terhadap interaksi yang berlangsung (Simms \& Jin, 2015). Anak dengan SCD sering salah menginterpretasikan apa yang orang lain katakan dan lakukan. Hal tersebut dikarenakan mereka sulit memahami 
komunikasi verbal maupun nonverbal. Mereka juga kesulitan dalam mengekspresikan diri mereka baik secara verbal ataupun nonverbal (Baird \& Norbury, 2015).

Individu dengan SCD pada lingkup sosial lebih sering canggung, tidak pantas, ataupun aneh. Penggunaan bahasa yang tidak cocok dan ketidakmampuan individu dalam membuat kesimpulan yang benar dapat mengganggu kemampuan mereka untuk berinteraksi dengan teman sebayanya dan mengakibatkan ia dijauhi oleh temannya, sehingga menimbulkan kecemasan dan frustasi (Mandy, Wang, Lee, \& Skuse, 2017).

Permasalahan yang dialami subjek saat ini adalah kurangnya penerimaan sosial karena subjek kesulitan dalam melakukan interaksi sosial dengan teman sebayanya. Hal tersebut mengakibatkan subjek terlihat pendiam, tidak memiliki teman, serta terlihat berbeda dari teman-temannya. Upaya untuk mencapai kebahagian seseorang memerlukan afeksi, keberhasilan dan penerimaan sosial (Grinder, 1978). Penerimaan sosial dapat diartikan sebagai perhatian positif dari orang lain.

Permasalahan ini terjadi karena ketidakmampuan subjek dalam memahami komunikasi baik verbal ataupun nonverbal serta subjek tidak bisa mengekspresikan dirinya. Kemampuan untuk interaksi dengan orang lain dibutuhkan subjek sehingga ia bisa berinteraksi dengan orang lain di sekitarnya tanpa adanya kesalahpahaman yang dimaksudkan. Oleh karena itu diperlukan intervensi untuk meningkatkan kemampuan subjek dalam interaksi sosial dengan teman sebayanya.

\section{Metode Asesmen}

Metode asesmen yang dilakukan untuk menegakkan diagnosa diantaranya adalah wawancara, observasi, dan tes psikologi. Wawancara dilakukan terhadap subjek yang bertujuan untuk memperoleh informasi mengenai riwayat permasalahan yang subjek alami. Wawancara terhadap keluarga subjek juga dilakukan untuk memperoleh informasi lebih mendalam mengenai riwayat masalah yang dialami subjek. Observasi dilakukan untuk memperoleh informasi seputar aktivitas yang dilakukan subjek sehari-hari dan memastikan perilaku-perilaku subjek yang mengarah pada problem yang dialaminya. Tes psikologi yang digunakan adalah tes intelegensi WISC untuk menggambarkan kondisi intelegensi subjek.

\section{Presentasi Kasus}

Subjek merupakan seorang anak perempuan berusia 8 tahun, anak pertama dari dua bersaudara. Saat ini subjek merupakan siswa kelas 2 di salah satu SD Negeri Mataram. Berdasarkan keterangan dari ibu, ia mengalami permasalahan pada perkembangannya. Pada saat hamil ibu subjek kesulitan untuk makan sehingga ibu subjek mudah sakit. Pada saat trimester akhir ibu subjek juga masih mengalami sulit makan oleh karena itu ibu subjek meminum susu dan suplemen yang diberikan oleh dokter untuk menjaga perkembangan janin. Sebulan terakhir sebelum melahirkan nafsu makan ibu subjek meningkat dan menghentikan untuk minum suplemen yang diberikan namun tetap meminum susu yang telah ada hingga proses melahirkan. Pada saat subjek lahir, ia tidak mengalami hambatan secara fisik. Proses perkembangannya pun tidak bermasalah pada tahun-tahun awal, namun demikian saat usia subjek 3 tahun, ibu subjek sering mengalami kesulitan dalam memahami makna dari kata-kata yang diucapkan subjek. Pada saat subjek diajak untuk bermain bersama teman-teman sesusianya ia akan lebih sering diam. Ibu subjek merasa khawatir dengan perkembangan subjek namun demikian ayah subjek mengatakan bahwa hal tersebut merupakan hal yang wajar untuk perkembangan subjek yang masih berumur 3 tahun. Sejak usia 3 bulan subjek diasuh oleh neneknya karena ibu dan ayah subjek bekerja. Ibu subjek juga mengakui bahwa nenek subjek jarang mengajarkan subjek cara untuk berinteraksi dengan orang lain. 
Subjek tidak mengalami banyak hambatan dalam proses belajar di sekolah. Menurut guru subjek, ia bisa memahami materi-materi yang disampaikan, namun demikian subjek sering memanggil gurunya dengan tidak sopan seperti memanggil temannya sendiri. Pada saat diberikan tugas berkelompok subjek juga mengalami hambatan karena banyak teman kelompoknya yang mengeluhkan subjek ketika melakukan tugas kelompok. Pada saat mendapatkan tugas untuk menyimpulkan sebuah cerita subjek kebingungan dalam memaknainya sehingga subjek cenderung salah dalam menyimpulkan cerita. Subjek cenderung tidak menunjukkan emosi ketika teman-temannya yang lain tertawa ataupun sedih. Oleh karena itu subjek kesulitan dalam memiliki teman bahkan ada beberapa teman-temannya yang sering mengganggunya di kelas.

Pola asuh orang tua subjek cenderung tidak konsisten antara orang tua dengan nenek subjek. Orang tua subjek cenderung tegas terhadap subjek sehingga subjek dituntut untuk belajar di rumah. Berbeda dengan nenek yang selalu memanjakan subjek dan selalu menuruti keinginan subjek. Orang tua subjek yang bekerja mengakibatkan waktu bersama subjek sangat sedikit sehingga jarang berinteraksi dengan subjek. Frekuensi subjek belajar bersama orang tuanya di rumah hanya pada malam hari untuk mengerjakan tugas-tugas yang diberikan sekolah, sedangkan hari sabtu subjek libur ia ikut dengan ibunya ke kantor karena tidak ada yang menjaganya di rumah. Orang tua subjek jarang mengajak subjek untuk belajar cara-cara dalam berkomunikasi ketika di lingkungan sosial. Kualitas pendampingan belajar di rumah cenderung kurang maksimal, subjek ditemani belajar namun belajar di depan televisi. Jika subjek tidak belajar maka subjek lebih memilih diam di rumah menonton telivisi ataupun bermain game dibandingkan ia keluar untuk bermain bersama teman seusianya.

Berdasarkan hasil tes intelegensi subjek mendapatkan IQ sebesar 91, menunjukkan bahwa subjek berada pada klasifikasi rata-rata. Hal ini menunjukkan bahwa subjek mampu menyelesaikan tugas-tugas yang diberikan dengan waktu yang cukup, artinya subjek cukup mampu dalam mengikuti proses belajar di sekolah. Hal ini menunjukkan bahwa subjek tidak memiliki masalah dengan fungsi kognitifnya, akan tetapi subjek memiliki kesulitan dalam berhubungan dengan orang lain.

Berdasarkan hasil asesmen yang telah dilakukan, subjek mengalami gangguan komunikasi sosial (SCD). Gangguan tersebut ditandai dengan subjek tidak mengetahui kata-kata untuk menyapa atau meminta maaf, tidak memahami cara berkomunikasi dengan konteks seperti menyamakan cara berbicara dengan teman dan guru, kesulitan dalam mengikuti aturan-aturan ketika dalam berkomunikasi ataupun kegiatan bercerita, serta kesulitan dalam memahami hal yang tidak disebutkan secara eksplisit seperti kesulitan dalam menyimpulkan sebuah cerita, serta memiliki permsalahan dalam interaksi sosial dengan teman-temannya sebayanya sehingga subjek tidak memiliki teman.

Social (pragmatic) Communication Disorder (SCD) atau gangguan komunikasi sosial merupakan kurangnya kemampuan dalam situasi sosial untuk berkomunikasi secara verbal ataupun nonverbal. Individu dengan SCD memiliki karakteristik seperti sulit menggunakan bahasanya dalam konteks sosial, kesulitan dalam mengikuti aturan dalam berkomunikasi, kesulitan dalam memahami bahasa seperti metafora, lelucon, dan lain sebagainya, serta kesulitan dalam mengintegrasi bahasa verbal dan nonverbal (Swineford, Thurm, Baird, Wetherby, \& Swedo, 2014). Hal ini ditandai dengan subjek memiliki kesulitan berbicara dalam lingkungan sosial, subjek tidak bisa mengikuti aturan-aturan dalam berkomunikasi seperti subjek akan berbicara keras ketika pelajaran sedang berlangsung, subjek tidak tertawa ketika ada lelucon yang disampaikan, serta subjek kurang mampu memaknai bahasa-bahasa nonverbal yang dilakukan oleh orang lain.

Interaksi sosial adalah hubungan yang terjadi dalam sekelompok individu yang saling berhubungan baik dalam berkomunikasi maupun melakukan tindakan sosial (Pebriana, 2017). 
Hubungan tersebut dapat terjadi antara individu dengan individu, individu dengan kelompok, atau kelompok dengan kelompok. Oleh karena itu dalam interaksi sosial antar individu harus mampu menyesuaikan diri satu sama lain (Gerungan, 2006). Interaksi sosial meliputi adanya kontak sosial berupa sapaan ataupun secara nonverbal, serta adanya komunikasi antar satu dengan yang lain memberikan informasi (Soekanto, 2002). Hal ini yang menjadi kesulitan dalam memiliki hubungan sosial dengan orang lain sehingga subjek kesulitan dalam memiliki teman baik di sekolah ataupun di lingkungan rumah. Subjek cenderung menghindar dalam situasi-situasi yang berhadapan dengan orang lain sehingga ia jarang berinteraksi dengan orang lain.

Penerimaan sosial merupakan suatu keadaan dimana keberadaan seseorang ditanggapi secara positif oleh orang lain dalan suatu hubungan yang dekat dan hangat dalam satu kelompok (Hurlock, 1973). Penerimaan sosial didefinisikan sebagai diterima dan diakuinya individu di dalam suatu kelompok sosial, individu tersebut dipandang secara positif oleh anggota kelompok sehingga individu tersebut dapat berperan aktif dalam kelompok sosialnya, dan dapat menyesuaikan diri dengan baik terhadap kelompok tertentu (Arsanti, 2016). Penerimaan sosial juga berarti dipilih sebagai teman untuk suatu aktifitas dalam kelompok dimana seseorang menjadi anggota (Hurlock, 1997). Subjek juga dihindari oleh teman-temannya. Teman-teman subjek cenderung mengabaikan subjek ketika bermain ataupun belajar. Hal tersebut juga mengakibatkan subjek cenderung tidak memiliki teman.

Pada saat bermain dengan teman sebaya, anak-anak cenderung memilih teman yang membuat mereka nyaman sehingga terbentuklah kelompok-kelompok dalam satu kelas (Hurlock, 2002). Hasil penelitian lain menerangkan bahwa anak-anak lebih suka bermain dengan teman yang memiliki sifat yang sama seperti dirinya dalam hal kompetensi sosial, orientasi sosial, emosi yang positif, perhatian, aktivitas motorik, dan keterampilan lingusitik (Brighi, Mazzanti, Guarini, \& Sansavini, 2015). Oleh karena itu teman-teman subjek tidak mengajak subjek untuk bermain bersama ataupun belajar bersama dalam kelompok karena menganggap subjek berbeda.

Faktor internal dan eksternal dapat mempengaruhi proses anak dalam menjalin hubungan sosial. Faktor internal meliputi kesehatan, intelegensi, minat dan motivasi. Faktor eksternal meliputi keluarga, sekolah, masyarakat, dan lingkungan sekitar. Hal ini mempengaruhi subjek dalam belajar menjalin hubungan sosial dan diterima oleh lingkungan sosialnya. Hal ini juga disebabkan karena SCD yang ia alami sehingga subjek kesulitan dalam berinteraksi sosial dengan orang lain. Pemberian penguatan mampu membuat anak mengulang perilaku yang diinginkan dan dapat terus dipertahankan (Dupaul, Weyandt, \& Janusis, 2011).

\section{Diagnosis dan Prognosis}

Hasil diagnosis subjek telah memenuhi kriteria diagnostik DSM-5 untuk gangguan Social (Pragmatic) Communication Disorder (SCD) (3.5.39/F80.89). Gangguan tersebut ditandai dengan subjek tidak mengetahui kata-kata untuk menyapa atau meminta maaf, tidak memahami cara berkomunikasi dengan konteks seperti menyamakan cara berbicara dengan teman dan guru, kesulitan dalam mengikuti aturan-aturan ketika dalam berkomunikasi ataupun kegiatan bercerita, serta kesulitan dalam memahami hal yang tidak disebutkan secara eksplisit seperti kesulitan dalam menyimpulkan sebuah cerita, serta memiliki permasalahan dalam penerimaan sosial dengan teman-temannya sebayanya sehingga subjek tidak memiliki teman.

Prognosis yang dimiliki subjek adalah baik dikarenakan permasalahan yang dimiliki memiliki faktor pencetus yang jelas, dukungan dari orang tua subjek yang ingin subjek menjadi lebih baik serta mau membantu subjek dalam melakukan pengobatan, kondisi lingkungan sekitar yang mendukung subjek, serta adanya ketertarikan subjek untuk menjadi anak yang lebih baik. 


\section{Intervensi}

Intervensi yang dilakukan adalah dengan menggunakan latihan keterampilan sosial. Social skill merupakan kemampuan individu yang berbeda pada masing-masing orang yang dapat menimbulkan akibat ketika berinteraksi dengan orang lain yang akhirnya sebagai bentuk suatu kesejahteraan sosial individu. Social skill diartikan sebagai kemampuan untuk berinteraksi baik berupa perilaku positif maupun negatif dan perilaku tersebut akan mendapat reinforcement ataupun punishment dari pihak lain (Segrin \& Taylor, 2007). SST merupakan metode atau cara yang dilakukan untuk memberikan gambaran perubahan perilaku setiap individu dalam mengerjakan fungisnya dengan tepat, baik di sekolah, di rumah maupun di lingkungan tempat tinggalnya (Cotugno, 2009).

SST bertujuan untuk meningkatkan keterampilan interpersonal pada subjek dengan gangguan hubungan interpersonal dengan melatih keterampilan subjek yang selalu digunakan dalam hubungan dengan orang lain dan lingkungan. Menurut Eikens (2000) latihan keterampilan sosial bertujuan untuk meningkatkan kemampuan seseorang dalam mengekspresikan apa yang dibutuhkan dan diinginkan. Tujuan berikutnya yaitu mampu menolak dan menyampaikan adanya suatu masalah, mampu memberikan respon saat berinteraksi sosial, mampu memulai interaksi, serta mampu mempertahankan interaksi yang telah dibina. Merubah perilaku dapat dipengaruhi oleh konsekuensinya, seperti memberi pujian atau penghargaan ketika anak mencoba keterampilan sosial dengan baik. Berikat adalah intervensi yang dilakukan:

Sesi 1: Membina raport dan menggali informasi Pada sesi ini terapis membangun raport dengan subjek sebaik mungkin agar intervensi dapat berjalan sesuai harapan. Terapis juga mulai menggali informasi lebih mendalam dari subjek, orang tua dan guru sekolah. Subjek mau bermain bersama terapis namun demikian subjek lebih banyak diam dan bermain sendiri. Subjek sedikit menceritakan bahwa ia tidak memiliki teman. Orang tua dan guru di sekolah subjek khawatir mengenai kondisi subjek yang tidak bisa memiliki teman. Teman-teman subjek lebih sering menghindari subjek dan jarang mengajaknya bermain bersama.

Sesi 2: Spesifikasi masalah dan penetapan tujuan Pada sesi ini, terapis menjelaskan mengenai permasalahan yang dihadapi oleh subjek, kemudian memberikan gambaran terbentuknya permasalahan yang sedang dihadapi. Tujuan dari sesi ini adalah membuat orang tua dan significant others mengetahui gambaran permasalahan subjek sehingga dapat mendukung berjalannya intervensi. Terapis menjelaskan intervensi yang akan diberikan kepada subjek serta manfaat dari intervensi jika dapat berjalan dengan baik. Orang tua subjek mulai memahami permasalahan subjek yaitu kurangnya penerimaan sosial terutama dari teman-teman sebaya subjek. Orang tua juga paham bahwa subjek seperti itu karena kurang memiliki kemampuan berinteraksi yang baik sehingga banyak orang lain yang menghindarinya.

Sesi 3: Modelling Pada sesi ini terapis menjelaskan secara spesifik kepada orang tua dan anak mengenai modeling yang akan dilakukan. Orang tua diberikan sebuah cerita dan memainkan peran yang akan di perhatikan oleh subjek sehingga ia bisa memahami cara interaksi dan hubungan sosial dengan orang lain. Keterampilan yang diajarkan berupa salam, memperkenalkan diri, serta bahasa nonverbal. Sesi ini orang tua membantu untuk bermain peran sesuai dengan cerita yang telah disiapkan. Sejak awal cerita orang tua subjek memulai dengan mengucapkan salam dan memperkenalkan dirinya. Anak memperhatikan cerita yang diperankan oleh orang tuanya dan beberapa kali bertanya mengenai cerita yang diperankan oleh orang tuanya.

Sesi 4: Role Play Pada sesi ini terapis menyampaikan petunjuk untuk pelaksanaan roleplay subjek, dilanjutkan dengan diskusi mengenai aktivitas yang akan diperankan. Latihan verbalisasi diperlukan melalui diskusi dengan menanyakan kepada subjek apa yang akan 
dilakukan apabila berada di situasi yang akan diperankan. Setelah diskusi selesai dilanjutkan dengan bermain peran. Pada tahap ini subjek juga diberikan pujian jika ia mampu memerankan apa yang sudah disepakati. Subjek memahami petunjuk pelaksanaan roleplay yang dilakukan. Aktivitas-aktivitas yang dipilih subjek berupa cerita yang diperankan oleh orang tuanya pada sesi sebelumnya. Terapis mencoba bertanya jika subjek mengambil barang milik temannya tanpa sepengetahuan yang punya subjek menjawab tidak tahu. Terapis membimbing subjek agar bisa mengatakan maaf setelah melakukan kesalahan. Beberapa kali subjek berhasil memerankan peran yang dipelajarinya dan mendapatkan pujian jika berhasil baik dari terapis maupun dari orang tua.

Sesi 5: Transfer training I Pada sesi ini subjek diminta untuk mencoba apa yang dilakukan ketika roleplay dilakukan dengan berinteraksi langsung dengan orang lain berupa teman sebayanya. Hal ini bertujuan untuk melatih kemampuan subjek berkomunikasi yaitu mengucapkan salam, memperkenalkan diri, serta menjawab pertanyaan dari lawan berbicara. Selain itu subjek juga berlatih untuk menggunakan bahasa tubuh atau komunikasi nonverbal.

Sesi 6: Transfer training IIPada sesi ini subjek dan terapis mengevaluasi kembali kekurangan pada sesi sebelumnya. Kemudian subjek berlatih kembali untuk menjalin persahabatan berupa memberikan pujian, meminta dan memberikan pertolongan kepada temannya, terlibat dalam aktivitas bersama, serta belajar menghadapi situasi sulit yakni menerima kritik, menerima penolakan, dan meminta maaf.

Sesi 7: Evaluasi dan terminasi Pada sesi ini subjek dan orang tua diminta untuk menceritakan apa saja yang telah didapatkan selama proses intervensi berlangsung serta perubahan-perubahan apa saja yang dirasakan oleh subjek dan orang tua subjek setelah mengikuti serangkaian intervensi. Terapis menjelaskan bahwa proses intervensi telah berakhir.

\section{Hasil dan Pembahasan}

\section{Hasil}

Intervensi yang dilakukan menunjukkan adanya peningkatan penerimaan sosial dari teman-teman sebaya subjek dilihat dari aktivitas-aktivitas yang dilakukan bersama-sama subjek dan teman-temannya setelah diberikan intervensi berupa latihan keterampilan sosial. Program yang dilakukan berupa melatih subjek untuk bisa melakukan interaksi yang tepat dengan teman-teman sebayanya dimulai dari modelling dengan orang tua, role play, hingga latihan terus menerus dengan teman sebayanya. Hasil dapat optimal apabila subjek dapat mengikuti serangkaian intervensi dan mentaati setiap kesepakatan yang telah disepakati. Oleh sebab itu sedikitnya perubahan yang dialami subjek merupakan kemajuan yang berarti dari proses intervensi. Tabel 1

Berdasarkan Tabel 1 subjek telah mengalami perkembangan yang cukup baik. Ia sudah mampu mengucapkan salam ketika bertemu dengan teman-temannya serta ketika masuk ke dalam rumah, yang sebelumnya subjek masuk langsung tanpa mengatakan apapun. Subjek mampu memahami bahasa-bahasa nonverbal yang dimunculkan orang lain dan bisa meresponnya dengan baik. Ia sudah mampu mengatakan maaf, meminta terlebih dahulu, dan mengucapkan terima kasih. Oleh karena itu teman-teman subjek sudah mulai mau menerima subjek dengan mengajak subjek bermain bersama-sama.

\section{Pembahasan}

Intervensi yang dilakukan dapat dikatakan berhasil sesuai dengan target intervensi yang telah disepakati. Latihan keterampilan sosial dapat dikatakan mampu meningkatkan penerimaan sosial pada anak dengan social (pragramit) communication disorder. Hasil intervensi ini menunjukkan adanya perubahan pola interaksi antara subjek dengan teman sebayanya. 
Tabel 1. Hasil perubahan perilaku sebelum dan sesudah intervensi

\begin{tabular}{lll}
\hline Sebelum Intervensi & Sesudah intervensi \\
\hline Subjek tidak mengucapkan salam ketika & Subjek mengucapkan salam terlebih \\
baru bertemu dengan teman-temannya & dahulu ketika masuk ke dalam rumah \\
dan masuk ke dalam rumah. & dan menyapa teman-temannya. \\
Subjek tidak bisa dikritik oleh & Subjek mendengarkan temannya yang \\
teman-temannya jika berbuat salah. & memberikan kritik terhadap dirinya. \\
Subjek kurang mampu memaknai & Subjek mampu memahami jika \\
bahasa-bahasa nonverbal yang & temannya mulai cemberut subjek \\
dilakukan oleh orang lain. & akan minta maaf terlebih dahulu. \\
Subjek tidak bisa memberikan pujian & Subjek bisa memberikan pujian \\
atas hasil dari orang lain. & terhadap hasil dari karya milik \\
& teman-temannya. \\
\hline
\end{tabular}

Teman-teman subjek sudah mulai mau mengajak subjek untuk bergabung dalam kelompok baik untuk bermain ataupun belajar.

Menurut Cartledge dan Milbun, latihan keterampilan sosial adalah kemampuan yang dapat dipelajari oleh seseorang sehingga memungkinkan orang tersebut berinteraksi dengan memberikan respon positif terhadap lingkungan dan mengurangi respon negatif yang mungkin hadir pada dirinya (Chen, 2006). Kneisl (2004) menyatakan bahwa latihan keterampilan sosial adalah metode yang didasarkan pada prinsip-prinsip sosial pembelajaran dan menggunakan teknik perilaku bermain peran, praktik dan umpan balik untuk meningkatkan kemampuan menyelesaikan masalah.

Subjek pertama mempelajari kemampuan untuk berkomunikasi dengan baik mempelajari dari orang tuanya, kemudian subjek belajar dengan cara meniru dan mencoba apa yang telah di lakukan orang tuanya secara terus menerus sehingga perilaku yang dipelajari berulang. Apabila subjek dihadapkan pada kondisi yang menuntunnya terus mengulang rutinitas yang diberikan maka perilaku yang dihadapkan akan terus diulang (Alter \& Alter, 2012; Pfiffner \& Haack, 2015).

Subjek sebelumnya adalah seorang anak yang kurang memiliki kemampuan dalam berkomunikasi dan melakukan interaksi sosial, namun demikian setelah pelaksanaan intervensi subjek lebih mampu dalam memulai untuk berkomunikasi dengan teman sebayanya dengan menyampaikan salam dan memperkenalkan diri. Subjek juga belajar untuk menyampaikan pendapatnya dengan pelan-pelan, tidak mengejek hasil dari karya yang dibuat oleh temannya, hingga meminta izin terlebih dahulu jika ingin meminjam barang milik temannya. Latihan keterampilan sosial dirancang untuk meningkatkan kemampuan berkomunikasi dan keterampilan sosial bagi seseorang yang mengalami kesulitan dalam berinteraksi meliputi keterampilan memberikan pujian, mengeluh karena tidak setuju, menolak permintaan orang lain, tukar menukar pengalaman, menuntut hak pribadi, memberi saran pada orang lain, pemecahan masalah yang dihadapi dan bekerjasama dengan orang lain (McQuaid et al., 2000).

Latihan keterampilan sosial merupakan hal penting untuk meningkatkan kemampuan seseorang berinteraksi dalam suatu lingkungan. Adanya kemampuan berinteraksi menjadi kunci untuk memperkaya pengalaman hidup, memiliki pertemanan, berpartisipasi dalam suatu kegiatan dan bekerjasama dalam suatu kelompok. Hal ini juga membuat subjek dapat diterima oleh teman-teman sebayanya. 


\section{Simpulan}

Intervensi dengan menggunakan latihan keterampilan sosial dapat meningkatkan penerimaan sosial pada anak dengan social (pragmatic) communication disorder. Hasil intervensi menunjukkan adanya peningkatan penerimaan sosial dari teman sebaya subjek. Hal ini ditandai dengan teman-teman subjek yang mau mengajak subjek untuk belajar dan bermain bersama. Adanya modelling dari orang tua dan roleplay yang dilakukan membantu subjek dalam mempelajari cara-cara berkomunikasi dengan orang lain.

\section{Referensi}

American Psychiatric Association. (2013). Diagnostic and statistical manual of mental disorder fifth edition DSM-5. Wilson Boulevard: Airlinton.

Alter, P., \& Alter, P. (2012). Preventing school failure: Alternative education for children and youth helping students with emotional and behavioral disorders solve mathematic word problems helping students with emotional and behavioral disorders solve mathematics word problems. Preventing School Failure, 56(1), $55-64$.

Arsanti, F. B. (2016). Tingkat penerimaan sosial terhadap keberadaan siswa difabel di MAN Maguwoharjo. Jurnal Bimbingan Dan Konseling, 5, 1, 1-9

Baird, G. \& Norbury, C. F. (2015). Social (pragmatic) communication disorders and autism spectrum disorder. Arch Dis Child, 0, 1-7.

Chen, K. (2006). Social skills intervention for students with emotional/behavioral disorders: A literature review from the American perspevtive. Educational Research and Reviews, 1(3), 143-149.

Cotugno, A. J. (2009). Social competence and latihan keterampilan sosial and intervention for children with autism spectrum disorders. J Autism Dev Disorder, 39(9), 68-77.

Dupaul, G. J., Weyandt, L. L., \& Janusis, G. M. (2011). ADHD in the classroom: Effective intervention strategies. Theory Into Practice, 50(35), 37-41.

Gerungan, W. A. (2006). Psikologi sosial. Bandung: Refika Aditama.

Grinder, R. E. (1978). Adolescence. Canada: John Wiley \& Sons Inc.

Hurlock, E. B. (1973). Adolescent development (Terjemahan). Tokyo: McGraw Hill Kogakusha.

Hurlock, E. B. (1997). Psikologi perkembangan, suatu pendekatan sepanjang rentang kehidupan. Jakarta: Erlangga.

Mandy, W., Wang, A., Lee, I., \& Skuse, D. (2017). Evaluating social (pragmatic) communication disorder. Journal of Child Psychology and Psychiatry, 58(10), 1166-1175.

Nissa, K., \& Masturah, A. N. (2019). Hubungan antara egonsentrisme dengan penerimaan sosial siswa regular terhadap siswa berkebutuhan khusus di sekolah inklusi. Psycho Holistic, 1, 38-46.

McQuaid, J. R., Granholm, E., McClure, F. S., .. \& Jeste, D. V. (2000). Development of an integrated cognitive-behavioral and latihan keterampilan sosial intervention for older patients with schizophrenia. $J$ Psychother Pract Res, 9(3), 149-156.

Pfiffner, L. J., \& Haack, L. M. (2015). Behavior management for school aged children with ADHD. Child Adolescent Psychiatry Clinic, 23(4), 731-746.

Segrin, C., \& Taylor, M. (2007). Positive interpersonal relationships mediate the association between social skills and psychological well-being. Personality and Individual Differences, 43, 637-646.

Simms, M. \& Jin, X. M. (2015). Autism, language disorder, and social (pragmatic) communication disorder: DSM-V and differential diagnoses. Pediatrics in Review, 36, 355-363.

Soekanto, S. (2002). Sosiologi Suatu Pengantar. Jakarta: Rajawali Pers.

Swineord, L. B., Thurm, A., Baird, G., Wetherby, A. M., Swedo, S. (2014). Social (pragmatic) communication disorder: A research review of this new DSM-V diagnostic category. Journal of Developmental Disorders, 4, 1-8.

Walgito, B. (2007). Psikologi Kelompok. Yogyakarta: Andi. 